\title{
成膜温度を変化させて作製した $\mathrm{YBa}_{2} \mathrm{Cu}_{3} \mathrm{O}_{7}+\mathrm{BaHfO}_{3}$ 薄膜の磁束ピンニング特性
}

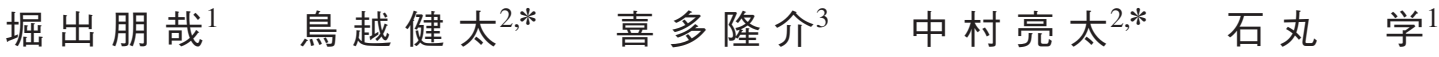 \\ 淡路智 ${ }^{4}$ 松本 要 ${ }^{1}$ \\ 1 九州工業大学大学院工学研究院物質工学研究系 \\ 2 九州工業大学大学院工学府物質工学専攻 \\ 3 静岡大学総合科学技術研究科 \\ ${ }^{4}$ 東北大学金属材料研究所
}

J. Japan Inst. Met. Mater. Vol. 83, No. 9 (2019), pp. 320-326

Special Issue on The Front Line of Superconducting Materials -Advances in Organizational Control Techniques toward Practical Use

(C) 2019 The Japan Institute of Metals and Materials

\section{Deposition-Temperature Dependence of Vortex Pinning Property in $\mathrm{YBa}_{2} \mathrm{Cu}_{3} \mathrm{O}_{7}+\mathrm{BaHfO}_{3} \mathrm{Film}$}

Tomoya Horide $^{1}$, Kenta Torigoe ${ }^{2, *}$, Ryusuke Kita ${ }^{3}$, Ryota Nakamura ${ }^{2, *}$, Manabu Ishimaru ${ }^{1}$, Satoshi Awaji ${ }^{4}$ and Kaname Matsumoto ${ }^{1}$

\footnotetext{
${ }^{1}$ Department of Materials Science and Engineering, Kyushu Institute of Technology, Kitakyushu 804-8550

${ }^{2}$ Department of Materials Science and Engineering, Kyushu Institute of Technology, Kitakyushu 804-8550

${ }^{3}$ Graduate School of Integrated Science and Technology, Shizuoka University, Hamamatsu 432-8561

${ }^{4}$ Institute for Materials Research, Tohoku University, Sendai 980-8577
}

\begin{abstract}
Improvement of critical current density $\left(J_{\mathrm{c}}\right)$ in magnetic fields is required in $\mathrm{YBa}_{2} \mathrm{Cu}_{3} \mathrm{O}_{7}$ films, and process parameters should be optimized for controlling pinning centers. In the present study, a deposition temperature was varied in pulsed laser deposition of $\mathrm{YBa}_{2} \mathrm{Cu}_{3} \mathrm{O}_{7}+\mathrm{BaHfO}_{3}$ films to control the nanorod structure, and its influence on $J_{\mathrm{c}}$ was analyzed. The $\mathrm{YBa}_{2} \mathrm{Cu}_{3} \mathrm{O}_{7}+\mathrm{BaHfO}_{3}$ film deposited at $850^{\circ} \mathrm{C}$ exhibited pinning force maximum $\left(F_{\mathrm{p}, \text { max }}\right)$ as high as $413 \mathrm{GN} / \mathrm{m}^{3}$ at $40 \mathrm{~K}$, while the $F_{\mathrm{p} \text {,max }}$ for the deposition temperature of $850^{\circ} \mathrm{C}$ at $77 \mathrm{~K}$ was smaller than that in the $\mathrm{YBa}_{2} \mathrm{Cu}_{3} \mathrm{O}_{7}+\mathrm{BaHfO}_{3}$ film deposited at $900^{\circ} \mathrm{C}$. A critical temperature decreased and matching field increased with decreasing the deposition temperature. Increase in deposition temperature is effective in improving the $F_{\mathrm{p}, \max }$ in high temperatures, since the critical temperature and matching field dependences of $J_{\mathrm{c}}$ value dominate the $F_{\mathrm{p} \text {,max }}$. On the other hand, low deposition temperature improves the $F_{\mathrm{p} \text {,max }}$ in low temperatures since the $F_{\mathrm{p}}$ shift in accordance with matching field is dominant to the $F_{\mathrm{p} \text {,max }}$. Thus, the deposition temperature should be set in pulsed laser deposition of $\mathrm{YBa}_{2} \mathrm{Cu}_{3} \mathrm{O}_{7}$ films containing nanorods considering the $J_{\mathrm{c}}$ variation with critical temperature and matching field. [doi:10.2320/jinstmet.JA201902]
\end{abstract}

(Received February 15, 2019; Accepted March 28, 2019; Published August 25, 2019)

Keywords: $\mathrm{YBa}_{2} \mathrm{Cu}_{3} \mathrm{O}_{7}$, vortex pinning, critical current density, nanorod, thin film

\section{1. 背 景}

高性能 $\mathrm{REBa}_{2} \mathrm{Cu}_{3} \mathrm{O}_{7}(\mathrm{REBCO} ; \mathrm{RE}=\mathrm{Y}, \mathrm{Nd}, \mathrm{Sm}, \mathrm{Gd}$, etc. $)$ 超伝 導テープ線材を開発するためには, 臨界電流密度 $\left(J_{\mathrm{c}}\right)$ の向上 が必要である ${ }^{1)}$. $J_{\mathrm{c}}$ 向上には磁束ピンニングセンターの導入 が有効であり, REBCO 超伝導テープ線材ではナノロッドや ナノ粒子を導入したナノコンポジット構造がピンニング特性 向上に有効である. パルスレーザー蒸着 $(\mathrm{PLD})^{2)}$ や有機金属 気相成長法 $(\mathrm{MOCVD})^{3)}$ を用いて REBCO テープ線材を作製 する際には, $\mathrm{BaMO}_{3}(\mathrm{BMO} ; \mathrm{M}=\mathrm{Zr}, \mathrm{Sn}, \mathrm{Hf}$, etc.) ナノロッドが 有効なピンニングセンターである ${ }^{4-7)}$. ナノロッドを有する

* 九州工業大学大学院生 (Graduate Student, Kyushu Institute of Technology)
ナノコンポジット構造の磁束ピンニング特性は, ナノロッド 密度, 長さ, 界面構造, ひずみ等の複数の構造パラメータに よって支配されている. 磁場の増加とともに量子化磁束密度 が大きくなることから, ナノロッド密度は磁場中のピンニン グ特性と強い相関がある ${ }^{8)}$. ナノロッドの長さや傾斜はナノ ロッドと量子化磁束が重なる体積, すなわちピンポテンシャ ルを決定する。ささらに界面の構造は要素ピン力に影響を及ぼ す可能性がある ${ }^{9)}$. またマトリックスのひずみは酸素空孔形 成エネルギーを介して臨界温度 $\left(T_{\mathrm{c}}\right)$ に影響することも明らか となっている ${ }^{10)}$. ナノロッドを導入した REBCO テープ線材 および薄膜において $J_{\mathrm{c}}$ をさらに向上させていくには，ナノ ロッド構造を精密に制御していく必要があり, 成膜プロセス の各条件が $J_{\mathrm{c}}$ 特性におよぼす影響を明らかにしたうえでプ ロセス最適化を進めていく必要がある.

PLD を用いた薄膜成長ではプルームからの原子の供給, 
表面拡散，核生成・成長が非平衡下で起こっており，単相薄 膜をPLDにおいて作製する場合には成膜温度，レーザー条 件, ターゲット組成等が重要である ${ }^{11-13)}$ 。ナノコンポジッ 卜薄膜成長はより複雑である。マトリックスと第二相を構成 する原子の拡散, 核形成・成長だけでなく, マトリックスと 第二相の島同士のコアレッセンス等複雑な過程を経てナノコ ンポジット構造が形成される。マトリックスやナノロッド材 料の選択はもちろん, 成膜温度や成膜レートなどの成膜条件 が異なれば，ナノロッド構造形成過程が大きく変化すると考 えられる14)，REBCOにおいてナノロッドを制御するため に，マトリックスの REとして $\mathrm{Y}, \mathrm{Nd}, \mathrm{Sm}, \mathrm{Eu}, \mathrm{Gd}$ 等，ま た $\mathrm{BMO}$ の $\mathrm{M}$ として $\mathrm{Zr}$ ， Hf， $\mathrm{Sn}$ 等が検討されてきた。 さら に成膜温度や成長速度を変化させることにより構造および $J_{\mathrm{c}}$ 特性が変化したことが報告されてきた，これらの中でも成膜 温度は極めて重要なパラメータであると考えられる。実際, 成膜温度によるナノロッドのサイズ，密度，長さの変化に関 し多岐にわたる報告がある。成膜温度が低温になるとナノ ロッドが切断されたり傾斜したりして成長し ${ }^{15)}$ ，ナノロッ ドの密度が増加することも報告された ${ }^{16)}$ 。これらの構造変 化を反映して $J_{\mathrm{c}}$ 特性が大きく変化してきた。 これらは成膜 温度を変化させることによりナノコンポジット構造を制御 し， $J_{\mathrm{c}}$ 特性を最大化する必要があることを示している.

本研究では, $\mathrm{YBa}_{2} \mathrm{Cu}_{3} \mathrm{O}_{7}+\mathrm{BaHfO}_{3}(\mathrm{YBCO}+\mathrm{BHO})$ 薄膜に着 目する。 $\mathrm{YBCO}+\mathrm{BHO}$ 薄膜作製プロセス条件のうち成膜温度 に着目し，PLDにおいて成膜温度を変化させることにより $\mathrm{YBCO}+\mathrm{BHO}$ 薄膜の磁束ピンニング特性を変化させた。超伝 導特性を評価したところ, 成膜温度によって $J_{\mathrm{c}}$ の磁場依存 性が大きく異なることが明らかになった。また $J_{\mathrm{c}}$ 值に関し ては特に $40 \mathrm{~K}$ で高いものが得られた。 $T_{\mathrm{c}}$ やマッチング磁場 をもとに $J_{\mathrm{c}}$ 特性機構を解析し, 成膜温度が YBCO+BHO 薄 膜の磁束ピンニング特性に及ぼす影響を議論する。

\section{2. 実 験 方 法}

試料作製はPLDにより行った. ターゲットを YBCO +BHO 混合ターゲットとし, BHO 添加量を $4.7 \mathrm{vol} \%$ と固定 した. 成膜時の酸素分圧は $26 \mathrm{~Pa}$ とし, 膜厚は Table 1 に示 した通りである。成膜温度は 830-900 $\mathrm{C}$ の間で変化させた。 なお成膜温度はサンプルホルダ裏面直上に配置した熱電対に よって計測した。また成膜後, $55000 \mathrm{~Pa}$ の酸素雾囲気で $1 \mathrm{~h}$

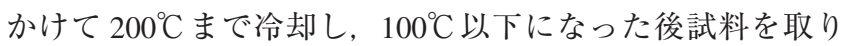

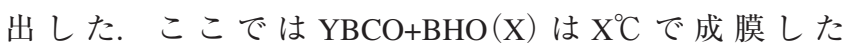
$\mathrm{YBCO}+\mathrm{BHO}$ 薄膜を意味する，YBCO 薄膜におけるナノロッ
ド構造を明らかにするために透過型電子顕微鏡 (TEM) 観察 を行った. フォトリソグラフィーと $\mathrm{H}_{3} \mathrm{PO}_{4}$ によるウエット エッチングを行い幅 $90 \mu \mathrm{m}$, 長さ $1 \mathrm{~mm}$ のブリッジを形成し た後, Physical Property Measurement System(PPMS)を用いて 超伝導特性評価を行った。電気抵抗の温度依存性を測定する ことにより $T_{\mathrm{c}}$ および不可逆温度 $\left(T_{\mathrm{irr}}\right)$ を求めた。 その後電流 密度-電界 $(J-E)$ カーブを測定することにより $J_{\mathrm{c}}$ を測定した. さらに $\mathrm{YBCO}+\mathrm{BHO}(850)$ に関しては東北大学金属材料研究 所の $20 \mathrm{~T}$ 超伝導マグネットを用いて $65 \mathrm{~K}$ および $40 \mathrm{~K}$ の温 度, $16 \mathrm{~T}$ までの磁場で $J_{\mathrm{c}}$ 測定を行った。磁場角度は $-90^{\circ} て ゙$ 磁場が $a b$ 面に平行に, $0^{\circ}$ では磁場が $c$ 軸に平行になるよう に定義し， $J_{\mathrm{c}}$ 磁場依存性の測定は $B / / c\left(0^{\circ}\right)$ のみで行った。 な お $J_{\mathrm{c}}$ および $T_{\mathrm{irr}}$ の基準として $1 \mu \mathrm{V} / \mathrm{cm}$ を用いた.ささらに $E \sim$ $J^{n}$ と表現した際の $n$ 值を $10-100 \mu \mathrm{V} / \mathrm{cm}$ の範囲で求めた.

\section{3. 結果}

$\mathrm{YBCO}+\mathrm{BHO}(850)$ の断面 TEM 観察結果を Fig. 1 に示す. 膜厚方向に途切れることなく成長したナノロッドが高密度に 存在していることがわかる。ナノロッドの間隔は 15-20 nm であり，サイズは $6 \mathrm{~nm}$ 程度である。ナノロッドの間隔から マッチング磁場を計算すると $B_{\Phi} \sim 6.8 \mathrm{~T}$ となる。 これまでに 報告されているナノロッド構造の成膜温度依存性の結果か $ら^{15)} ， 850^{\circ} \mathrm{C}$ り成膜温度の高い温度でも途切れることなく ナノロッドが成長していると考えられる。

Fig. 2 に $77 \mathrm{~K}$ における $J_{\mathrm{c}}$ の磁場依存性を示す．成膜温度

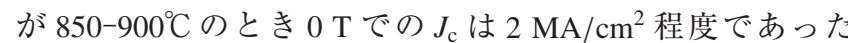
が, $\mathrm{YBCO}+\mathrm{BHO}(830)$ では $J_{\mathrm{c}}$ が $0.3 \mathrm{MA} / \mathrm{cm}^{2}$ 程度であった。 $\mathrm{YBCO}+\mathrm{BHO}(890)$ と $\mathrm{YBCO}+\mathrm{BHO}(900)$ では $J_{\mathrm{c}}$ 磁場依存性が ほほ同じであり, $4 \mathrm{~T}$ 以上で $J_{\mathrm{c}}$ が急激に減少した. $\mathrm{YBCO}+\mathrm{BHO}(850)$ では $J_{\mathrm{c}}$ の磁場依存性は $\mathrm{YBCO}+\mathrm{BHO}(890)$ や YBCO+BHO (900) と異なり，6 T 以上の磁場で $J_{\mathrm{c}}$ が急激

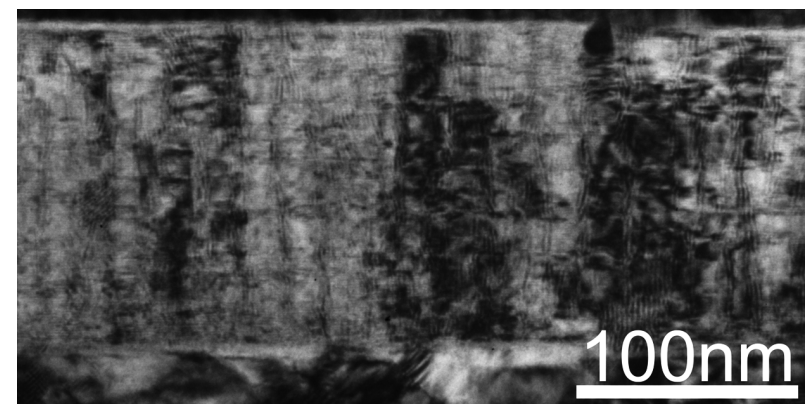

Fig. 1 TEM image of the $\mathrm{YBCO}+\mathrm{BHO}$ (850) film.

Table 1 Parameters of the $\mathrm{YBCO}+\mathrm{BHO}$ films prepared in the present study.

\begin{tabular}{ccccccc}
\hline & $\begin{array}{c}\text { Thickness } \\
/ \mathrm{nm}\end{array}$ & $\begin{array}{c}T_{\mathrm{c}, 0} \\
/ \mathrm{K}\end{array}$ & $\begin{array}{c}J_{\mathrm{c}}(77 \mathrm{~K}, 0 \mathrm{~T}) \\
/ \mathrm{MA} / \mathrm{cm}^{2}\end{array}$ & $\begin{array}{c}J_{\mathrm{c}}(77 \mathrm{~K}, 5 \mathrm{~T}) \\
/ \mathrm{MA} / \mathrm{cm}^{2}\end{array}$ & $\begin{array}{c}n \text { value at } \\
77 \mathrm{~K}, 2 \mathrm{~T}\end{array}$ & $\begin{array}{c}J_{\mathrm{c}}(20 \mathrm{~K}, 9 \mathrm{~T}) \\
/ \mathrm{MA} / \mathrm{cm}^{2}\end{array}$ \\
\hline YBCO+BHO(900) & 150 & 87.9 & 2.3 & 0.34 & 13.2 & 3.3 \\
$\mathrm{YBCO}+\mathrm{BHO}(890)$ & 120 & 88.0 & 2.1 & 0.28 & 10.8 & 4.2 \\
$\mathrm{YBCO}+\mathrm{BHO}(850)$ & 140 & 86.1 & 2.6 & 0.28 & 9.9 & 6.8 \\
YBCO+BHO(830) & 200 & 83.5 & 0.26 & 0.012 & 4.0 & 2.3 \\
\hline
\end{tabular}


に減少した. さらに巨視的ピン力 $\left(F_{\mathrm{p}}=J_{\mathrm{c}} B\right)$ の磁場依存性を Fig. $2(\mathrm{~b})$ に示す. $890^{\circ} \mathrm{C}, 900^{\circ} \mathrm{C}$ の成膜では $F_{\mathrm{p}}$ は $4 \mathrm{~T}$ で最大 值を示し, $\mathrm{YBCO}+\mathrm{BHO}(900)$ において本研究の中で最も大き な值である $19.3 \mathrm{GN} / \mathrm{m}^{3}$ が得られた。 $\mathrm{YBCO}+\mathrm{BHO}(850)$ では $6 \mathrm{~T}$ で $F_{\mathrm{p}}$ の最大值 $15.1 \mathrm{GN} / \mathrm{m}^{3}$ を示した. 一方, $\mathrm{YBCO}+\mathrm{BHO}$ (830)では $77 \mathrm{~K}$ での $J_{\mathrm{c}}$ および $F_{\mathrm{p}}$ が他の膜と比較して 1 桁以 上小さかった。このように $77 \mathrm{~K}$ の $J_{\mathrm{c}}$ は成膜温度に大きく依 存し, 成膜温度の減少とともに $F_{\mathrm{p}, \max }$ は小さくなることがわ かった。 また Table 1 に $20 \mathrm{~K}, 9 \mathrm{~T} の J_{\mathrm{c}}$ も示した. 高温(77 K) 低磁場では $\mathrm{YBCO}+\mathrm{BHO}(900)$ で高い $J_{\mathrm{c}}$ を示す傾向にあっ

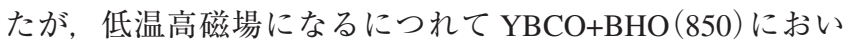
て $J_{\mathrm{c}}$ が高くなることがわかる. $\mathrm{YBCO}+\mathrm{BHO}(830)$ では他の 薄膜と比較して $77 \mathrm{~K}$ の $J_{\mathrm{c}}$ が極めて小さかったが, $20 \mathrm{~K}, 9$ $\mathrm{T}$ では同程度の $J_{\mathrm{c}}$ となった. しかし $T_{\mathrm{c}}$ が低いことが原因の 一つとなって, $20 \mathrm{~K}, 9 \mathrm{~T}$ においてもその他の試料よりも $J_{\mathrm{c}}$ が高くなるには至らなかった。

Fig. 2 の結果から低温高磁場で高い特性が期待される $\mathrm{YBCO}+\mathrm{BHO}(850)$ の $65 \mathrm{~K}, 40 \mathrm{~K}$ における $J_{\mathrm{c}}$ 特性を Fig. 3 に 示す. $\mathrm{YBCO}+\mathrm{BHO}(850)$ の $F_{\mathrm{p}}$ は $65 \mathrm{~K}, 40 \mathrm{~K}$ では 7-8 T で最 大值となった。これらは $77 \mathrm{~K} て ゙ F_{\mathrm{p}}$ が最大となった磁場とほ ぼ同じであり，マッチング磁場が $F_{\mathrm{p}, \max }$ を決定していること
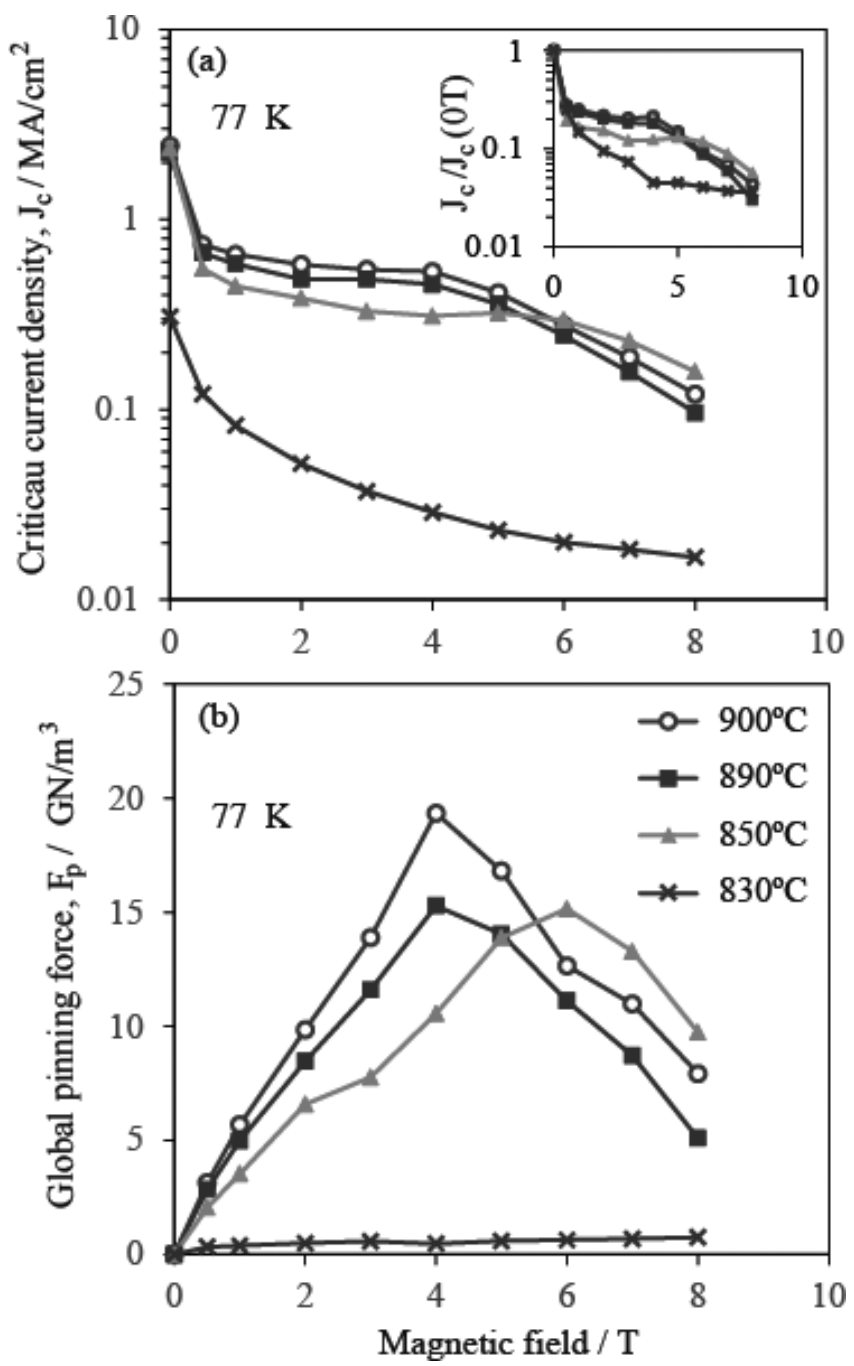

Fig. 2 Magnetic field dependences of (a) $J_{\mathrm{c}}$ and (b) $F_{\mathrm{p}}$ at $77 \mathrm{~K}$ for the $\mathrm{YBCO}+\mathrm{BHO}$ films.
がわかる. $F_{\mathrm{p}, \max }$ の值は $65 \mathrm{~K}$ で $103 \mathrm{GN} / \mathrm{m}^{3}, 40 \mathrm{~K}$ で 413 $\mathrm{GN} / \mathrm{m}^{3}$ となった. また Fig. 3 には $\mathrm{YBCO}+\mathrm{BHO}(850)$ におけ る $65 \mathrm{~K}$ の $J_{\mathrm{c}}$ 角度依存性も示した. $\mathrm{YBCO}+\mathrm{BHO}(850)$ は大き な $c$ 軸ピークを示し, $\mathrm{YBCO}+\mathrm{BHO}(850)$ ではナノロッドが まっすぐに伸びた強い $c$ 軸相関ピンとして機能していること を示している.

$J_{\mathrm{c}}$ 特性を議論するためにマッチング磁場 $\left(B_{\Phi}\right)$ と $T_{\mathrm{c}}$ が重要 なパラメー夕となる. Fig. 4 にそれぞれの試料における抵 抗一温度 $(R-T)$ 曲線を示す. $90 \mathrm{~K}$ 近傍で抵抗が低下し始め, 88-83 Kで抵抗がゼロとなった. $\mathrm{YBCO}+\mathrm{BHO}(900)$ と $\mathrm{YBCO}+\mathrm{BHO}(890)$ では $88 \mathrm{~K}$ 近傍でシャープな超伝導転移が 見られている。しかし $\mathrm{YBCO}+\mathrm{BHO}(850)$ と $\mathrm{YBCO}+\mathrm{BHO}$ (830)では超伝導転移が 2 段階になっているように見え, 特 に YBCO+BHO(830)ではその傾向が顕著である.これは低 温で成膜したことによる組成ずれの影響が原因であると考え られる． $T_{\mathrm{c} 0}$ の成膜温度依存性を Fig. $4(\mathrm{~b})$ に示す. $R-T$ 曲線 からわかるとおり， $T_{\mathrm{c} 0}$ は成膜温度の減少とともに小さく なっており, $T_{\mathrm{c} 0}$ の減少は 2 段階超伝導転移の影響を強く受 けていることがわかる.

$B_{\Phi}$ を議論するために Fig. 5 に不可逆磁場曲線を示す. 低 磁場では $T_{\text {irr }}-B$ 曲線が急激に立ち上がり, 折れ曲がりを見せ た後 $T_{\text {irr }}$ は磁場に対して直線的に減少していく. 横軸を $1-$ $T / T_{\mathrm{c}}$ として不可逆磁場曲線を表示したものが Fig. 5(b)であ る. 高磁場側, 低磁場側それぞれの $T_{\mathrm{irr}}-B$ 挙動は成膜温度に よって変化しないが, 振る舞いが変化する磁場が成膜温度に

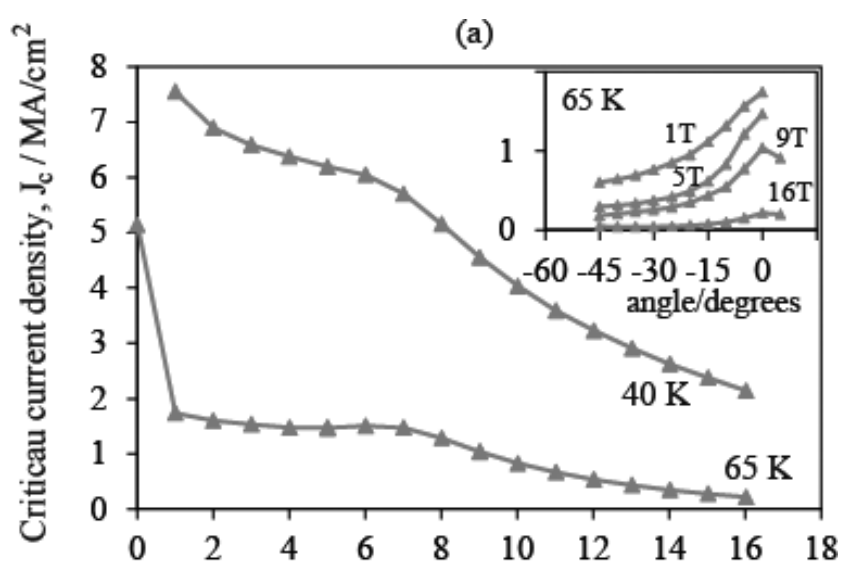

(b)

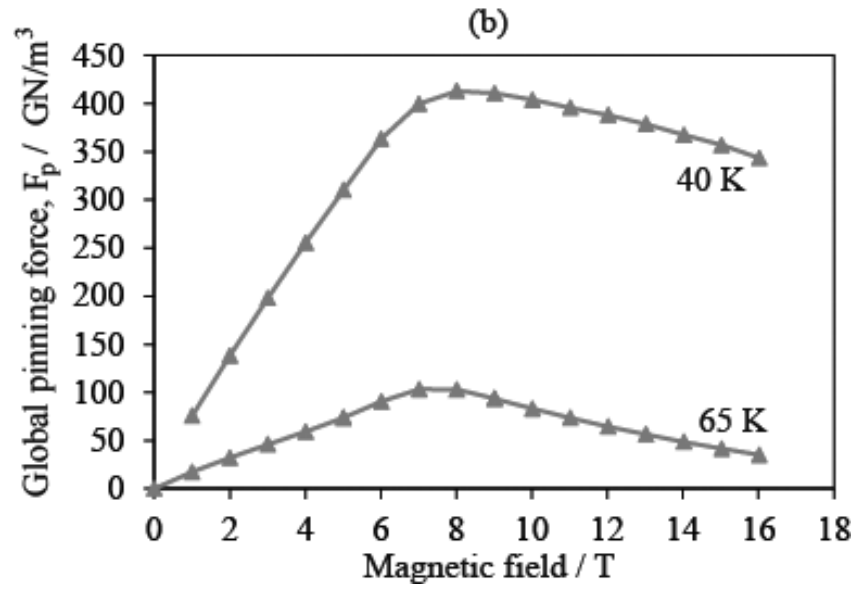

Fig. 3 Magnetic field dependences of (a) $J_{\mathrm{c}}$ and (b) $F_{\mathrm{p}}$ in temperatures of $40 \mathrm{~K}$ and $65 \mathrm{~K}$ for the $\mathrm{YBCO}+\mathrm{BHO}(850)$ film. 
(a)
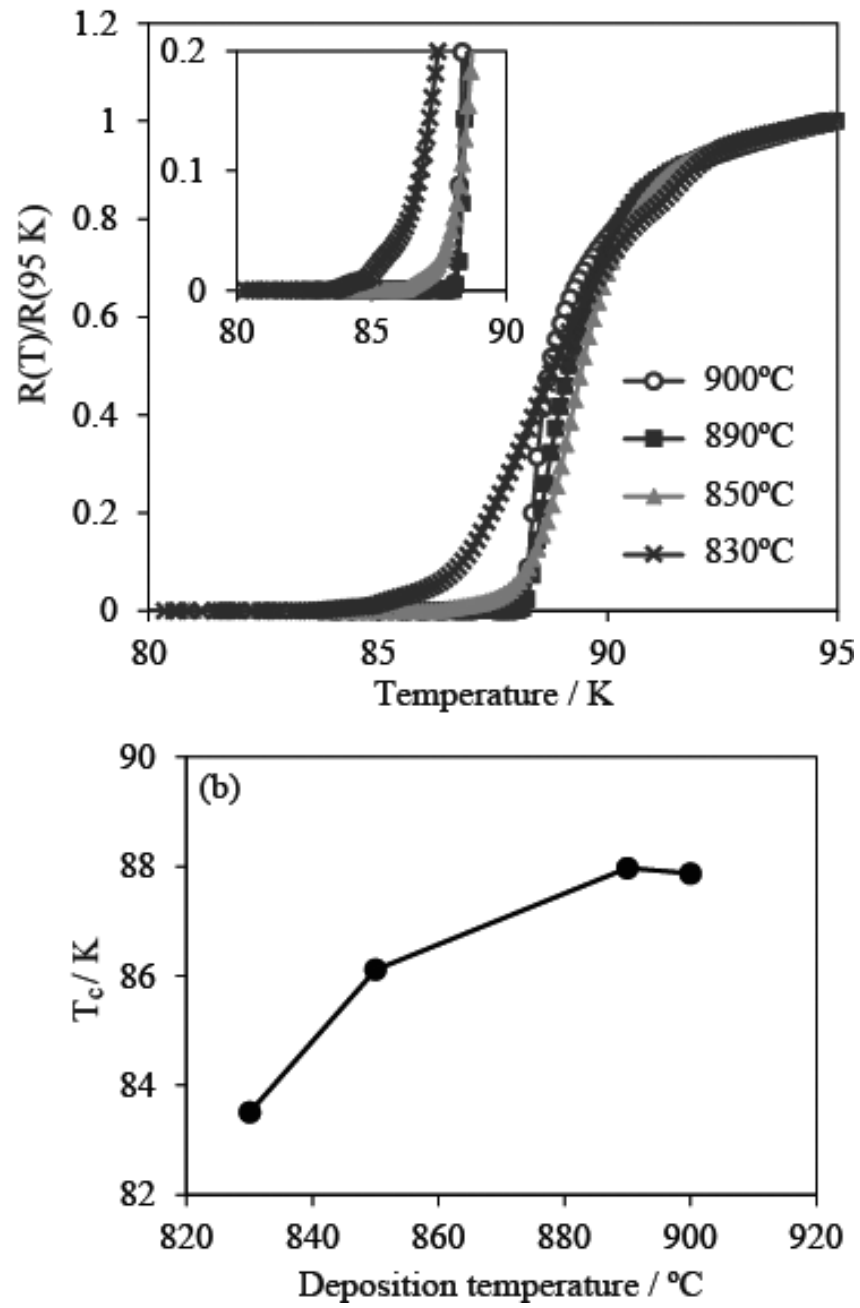

Fig. 4 (a) $R(\mathrm{~T}) / R(95 \mathrm{~K})-T$ curves in the YBCO+BHO films. Inset shows the enlarged view. (b) Deposition-temperature dependence of $T_{\mathrm{c} 0}$.

強く依存していることが Fig. 5(b)からわかる. $T_{\mathrm{irr}}-B$ におい て折れ曲がりが見られた磁場が $B_{\Phi}$ に対応することが知られ ており ${ }^{8)}, T_{\mathrm{irr}}{ }^{-B}$ の折れ曲がりから求めた $B_{\Phi}$ の成膜温度依存 性を Fig. $5(\mathrm{c})$ 示す. TEM で求めた $B_{\Phi}$ との違いの一因は断面 観察によるナノロッド間隔測定の精度の問題であると考えら れる．また低温における $F_{\mathrm{p}}$ のピーク位置との違いは低温に おけるランダムピンの寄与の可能性が考えられる. Fig. 5 (c) は成膜温度を小さくするにつれて, 拡散距離が減少しナノ ロッド間隔が減少したことを示唆している. 過去の報告で も，YBCO+BHOでも成膜温度が低下するにしたがって $T_{\mathrm{c}}$ が減少し， $B_{\Phi}$ が増加することを報告した ${ }^{17)}$. 成膜温度依存 性の強さや温度範囲の違いは基板加熱部の構造や成膜レート 等の条件が異なっていることが原因であると考えられるが, 成膜温度に対する $T_{\mathrm{c}}$ および $B_{\Phi}$ の傾向は過去の報告と同じで あることがわかる。

\section{4. 考察}

Table 2 に今回の結果とこれまでに文献において報告され ている高い $J_{\mathrm{c}}$ に関する結果を比較する ${ }^{18-20)}$. $77 \mathrm{~K}$ の $F_{\mathrm{p}, \max }$
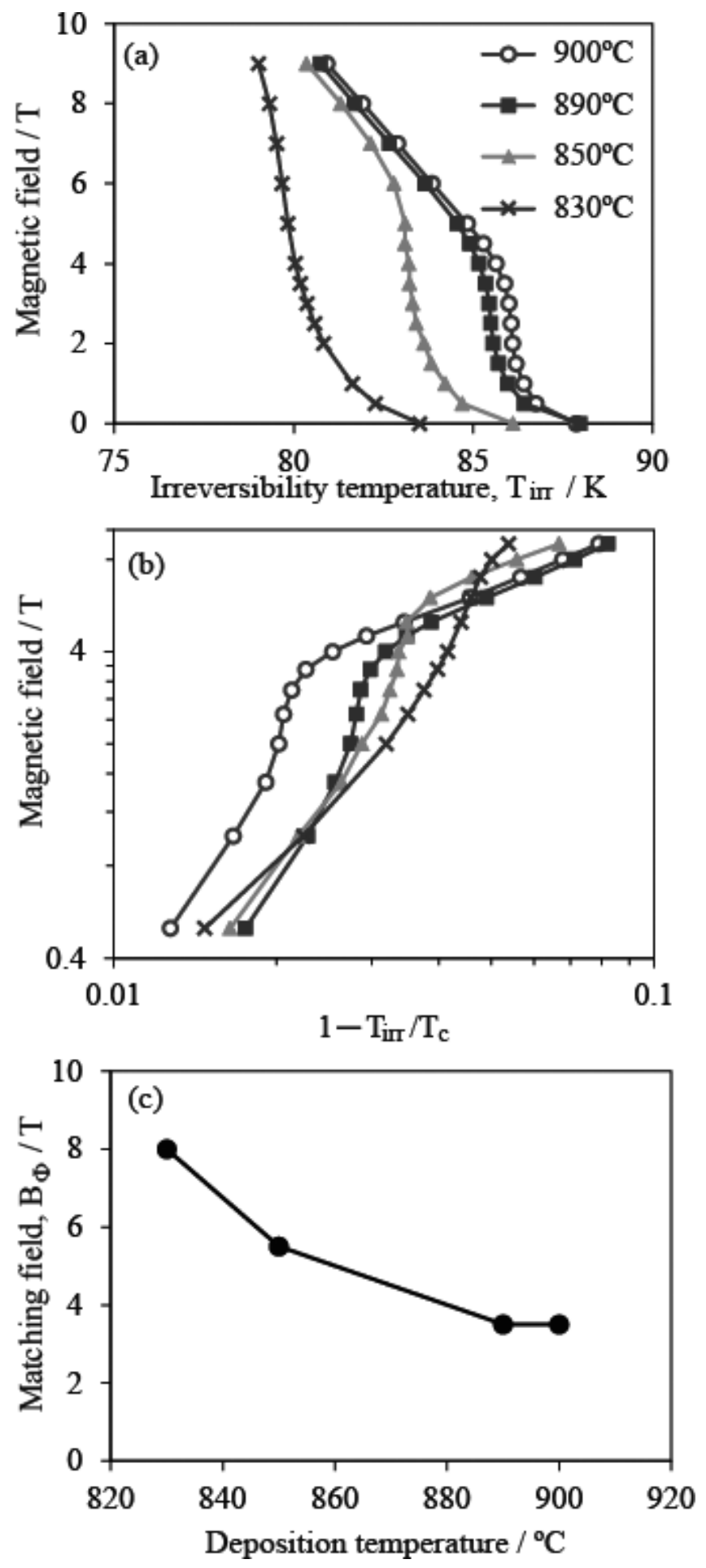

Fig. 5 (a) $T_{\text {irr }}-B$ curves and (b) $\left(1-T_{\text {irr }} / T_{\mathrm{c}}\right)-B$ curves for the YBCO+BHO films. (c) Deposition-temperature dependence of $B_{\Phi}$ in the YBCO+BHO films.

$=15 \mathrm{GN} / \mathrm{m}^{3}$ は過去に報告されているものと比較してそれほ

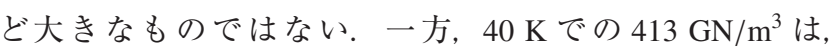
SmBCO+BHO において報告された ${ }^{18,19)} 400-407 \mathrm{GN} / \mathrm{m}^{3} よ り$ もわずかに高い(ほぼ同等の)值であり, $40 \mathrm{~K} て ゙$ 報告されて いるものの中では高い特性といえる.このように $\mathrm{YBCO}$ $+\mathrm{BHO}(850)$ において特に $40 \mathrm{~K}$ で高い $F_{\mathrm{p}, \max }$ が得られており, この要因について $T_{\mathrm{c}}$ と $B_{\Phi}$ をもとに議論する. 
Table 2 High $J_{\mathrm{c}}$ and $F_{\mathrm{p}}$ values in the present study and literatures ${ }^{18-21)}$. A peak field denotes the magnetic field where $F_{\mathrm{p}, \max }$ is observed.

\begin{tabular}{|c|c|c|c|c|c|c|c|}
\hline Sample & $\begin{array}{l}T_{\mathrm{c}} / \\
\mathrm{K}\end{array}$ & $B_{\Phi} / \mathrm{T}$ & $\begin{array}{l}F_{\mathrm{p}, \max }(77 \\
\mathrm{K}) / \\
\mathrm{GN} / \mathrm{m}^{3}\end{array}$ & $\begin{array}{l}\text { Peak } \\
\text { field (77 } \\
\mathrm{K}) / \mathrm{T}\end{array}$ & $\begin{array}{l}F_{\mathrm{p}, \max } \\
(40 \mathrm{~K}) / \\
\mathrm{GN} / \mathrm{m}^{3}\end{array}$ & $\begin{array}{l}\text { Peak } \\
\text { field } \\
(40 \mathrm{~K}) / \\
\mathrm{T}\end{array}$ & Remarks \\
\hline YBCO & & & & & & & \\
\hline $\begin{array}{l}+\mathrm{BHO} \\
(850)\end{array}$ & 86.1 & 6.8 & 15.1 & 6 & 413 & 8 & \\
\hline $\begin{array}{l}\mathrm{SmBCO} \\
+\mathrm{BHO}^{18)}\end{array}$ & 91.1 & 5.8 & 32.5 & 5 & 400 & 5 & \\
\hline $\begin{array}{l}\mathrm{SmBCO} \\
+\mathrm{BHO}^{19)}\end{array}$ & 91 & 9.9 & 14.2 & 6 & 407 & 10 & \\
\hline $\begin{array}{l}\text { GdBCO } \\
+\mathrm{BHO}^{20)}\end{array}$ & 89.1 & 4.1 & 22.5 & 5.5 & 285 & 7 & \\
\hline $\begin{array}{l}(\mathrm{Gd}, \mathrm{Y}) \mathrm{BCO} \\
+20 \% \mathrm{Zr}^{3)}\end{array}$ & 90 & & $22 *$ & $3-5^{*}$ & $365^{*}$ & $5-9 *$ & $\begin{array}{l}{ }^{*} \text { The } F_{\mathrm{p}} \text { was } \\
\text { obtained from } \\
\text { the reported } \\
J_{\mathrm{c}}-B \text { curves. }\end{array}$ \\
\hline
\end{tabular}

\section{$4.1 J_{\mathrm{c}}$ の磁場依存性}

$77 \mathrm{~K}$ では $\mathrm{YBCO}+\mathrm{BHO}(900)$ や $\mathrm{YBCO}+\mathrm{BHO}(890)$ の方が $\mathrm{YBCO}+\mathrm{BHO}(850)$ よりも $F_{\mathrm{p}, \max }$ が大きくなった. ナノロッド サイズは成膜温度の減少とともに小さくなると考えられ, $\mathrm{YBCO}+\mathrm{BHO}(850)$ ではナノロッドの直径が $6 \mathrm{~nm}$ 程度であっ た.ナノロッドサイズが磁束サイズよりも小さい場合はナノ ロッドと磁束が重なる体積がピンポテンシャルを決める可能 性がある。しかしこのようにして決まるピンポテンシャルか ら求められる $J_{\mathrm{c}}(0 \mathrm{~T})$ は実験值よりも極めて大きく, 直接ナ ノロッドからデピンニングされるわけではなくハーフループ やダブルキンクなどの磁束励起機構が働いていることが示唆 されている朕。実際実験ではYBCO+BHO (900), $\mathrm{YBCO}+\mathrm{BHO}(890), \mathrm{YBCO}+\mathrm{BHO}(850)$ の $77 \mathrm{~K}$ での $J_{\mathrm{c}}(0 \mathrm{~T})$ が 同程度であり, ナノロッドサイズの違いが $J_{\mathrm{c}}(0 \mathrm{~T})$ に現れて いない. これは直接デピンニングが $J_{\mathrm{c}}$ を支配しているわけ ではないために，サイズが異なるナノロッドに対して同程度 の $J_{\mathrm{c}}(0 \mathrm{~T})$ が得られたと考えられる。 また過去の研究でナノ ロッドサイズの効果は温度とともに小さくなり， $77 \mathrm{~K}$ 以下 ではナノロッドサイズの効果が見えなくなることも示してお $り^{22)}$, 本研究の結果は過去の結果とも矛盾しない。これら の結果からナノロッドサイズの影響は本研究の $J_{\mathrm{c}}$ の違いに 支配的でないと考えられる，そこで $J_{\mathrm{c}}$ の違いを理解するた めに $J_{\mathrm{c}}(B) / J_{\mathrm{c}}(0 \mathrm{~T})$ の $B_{\Phi}$ 依存性を考える. Fig. 2 では $B_{\Phi}$ の小 さい $\mathrm{YBCO}+\mathrm{BHO}(900)$ で $J_{\mathrm{c}}\left(B<B_{\Phi}\right) / J_{\mathrm{c}}(0 \mathrm{~T})$ が大きくなって いる. またこれまでに $n$ 值 ${ }^{23)}$ やクリープ解析 ${ }^{14)}$ 等を用いて 磁束運動が議論されている. Table 1 に $77 \mathrm{~K} ， 2 \mathrm{~T}$ における $n$ 值を示したが, 本研究では低温成膜試料で $n$ 值が小さくなっ ている、YBCO+BMOにおいて広範囲に $B_{\Phi}$ を変化させて $J_{\mathrm{c}}(B) / J_{\mathrm{c}}(0 \mathrm{~T})$ を評価した結果， $B_{\Phi}$ が大きくなるにつれて $J_{\mathrm{c}}\left(B<B_{\Phi}\right) / J_{\mathrm{c}}(0 \mathrm{~T})$ が小さくなったことをすでに報告してい
$ろ^{8)}$. これはダブルキンクやハーフループ機構によって磁束 がナノロッド間を運動する際， $B_{\Phi}$ が大きい，つまりナノ ロッド間隔が狭い方が量子化磁束の飛び移りが大きくなるた めであると考えられる. 本研究でも同様の機構により $J_{\mathrm{c}}\left(B<B_{\Phi}\right) / J_{\mathrm{c}}(0 \mathrm{~T})$ の $B_{\Phi}$ 依存性が現れたと考えられる.

一方で $B_{\Phi}$ が増加すると高密度の量子化磁束をピンニング できるようになるため, 高磁場でも高い $J_{\mathrm{c}}$ を保つことがで きるようになる。十分なピンニングサイトがあるため YBCO+BHO (850) では 1-7 T で $J_{\mathrm{c}}$ がほぼ一定である．磁場 が増加してすべてのピンニングセンターが量子化磁束により 占有されてしまうと, 弾性相互作用により量子化磁束がピン ニングされるようになり，J $J_{\mathrm{c}}$ が急激に低下していく，J $J_{\mathrm{c}}$ が一 定となる領域, つまり高磁場までナノロッドによる直接的な ピンニング領域を高磁場まで広げることができたため, $F_{\mathrm{p}, \text { max }}$ が高磁場側にシフトし YBCO+BHO $(850)$ の低温での $F_{\mathrm{p}, \text { max }}$ が大きくなった.

\section{$4.2 T_{\mathrm{c}}$ の効果}

$T_{\mathrm{c}}$ の違いも $J_{\mathrm{c}}$ に大きく影響を及ぼすと考えられる. Fig. 6 (a)において YBCO+BMO における $J_{\mathrm{c}}(77 \mathrm{~K}, 0 \mathrm{~T})$ の $T_{\mathrm{c}}$ 依存性 を示す. 本研究の結果に加え, Table 2 に示した文献の結

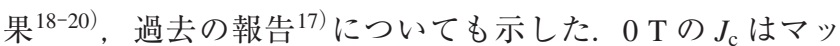
チング磁場の効果はないと考えられるため, 異なる $B_{\Phi}$ を有 する試料の結果が Fig. 6(a)に示されている. 2 段階転移して いることを考慮するために $T_{\mathrm{c}}{ }^{\text {onset }}$ 以下の温度において急激に 抵抗が減少している部分を $R=0$ まで外抻して $T_{\mathrm{c}}^{\text {str }}$ とした. $T_{\mathrm{c} 0}$ は超伝導パスの中で最も超伝導状態が弱められている部 分が検出されるのに対し, $T_{\mathrm{c}}^{\mathrm{s}}$ st は超伝導パスの中で超伝導状 態が強い部分を表す，超伝導領域全体に電流が流れた際の電 圧発生を評価することによって得られる $J_{\mathrm{c}}$ は $T_{\mathrm{c}}^{\mathrm{str}}$ によって 決まっていると考えられ, 実際 $T_{\mathrm{c} 0}$ よりも $T_{\mathrm{c}}$ str で議論したほ 

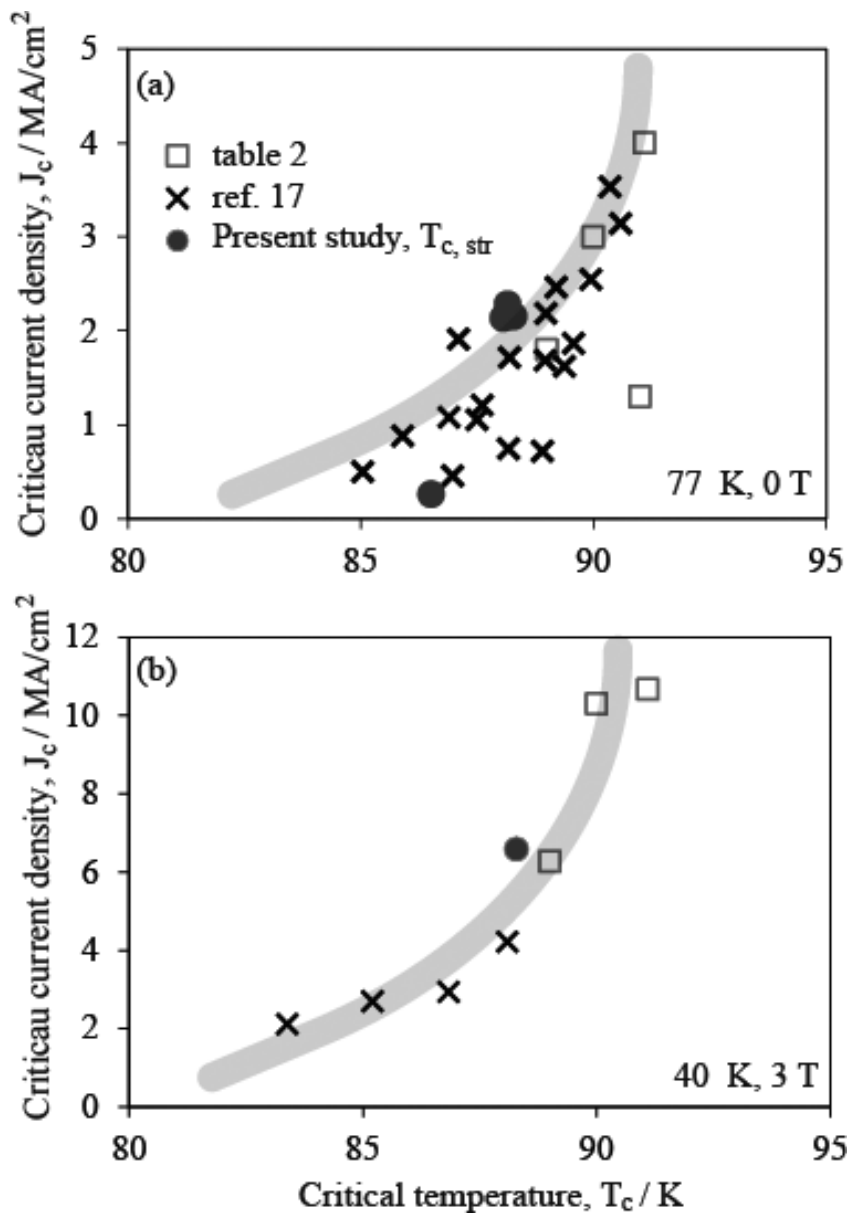

Fig. 6 (a) $T_{\mathrm{c}}\left(T_{\mathrm{c}}{ }^{\text {str }}\right)$ dependence of $J_{\mathrm{c}}(77 \mathrm{~K}, 0 \mathrm{~T})$ in the present YBCO+BHO films, our previous report, and the samples in Table 2. (b) $T_{\mathrm{c}}\left(T_{\mathrm{c}}{ }^{\text {str }}\right)$ dependence of $J_{\mathrm{c}}(40 \mathrm{~K}, 3 \mathrm{~T})$ for the samples with matching field of 4-7 T.

うが $J_{\mathrm{c}}$ 值を説明できることをすでに明らかにしている ${ }^{17)}$. 一部傾向が外れるものもあるが， $T_{\mathrm{c}}$ の増加とともに試料に よらず $J_{\mathrm{c}}(77 \mathrm{~K}, 0 \mathrm{~T})$ は増加していく傾向があることがわか る。なお一部試料において傾向が外れた原因は, 試料の不均 一性により超伝導電流パスの有効断面積が減少したこと, ナ ノロッドの形態変化(例えば低温成膜の影響で成長方向が傾 斜したことなど)によると考えられる.さらに本研究の試料, 過去に報告した試料 ${ }^{17)}$, Table 2 の試料について $J_{\mathrm{c}}(40 \mathrm{~K}, 3 \mathrm{~T})-T_{\mathrm{c}}\left(T_{\mathrm{c}}^{\mathrm{str}}\right)$ を Fig. 6(b) に示した。磁場中 $J_{\mathrm{c}}$ は $B_{\Phi}$ に強く影響を受けるため, Fig. 6(b) は $B_{\Phi}=4-7 \mathrm{~T}$ のものにつ いて議論する。 なお文献 19) は $B_{\Phi}=10 \mathrm{~T}$ とやや $B_{\Phi}$ が大きい ことから Fig. 6(b) から除外した。 $J_{\mathrm{c}}(77 \mathrm{~K}, 0 \mathrm{~T})$ 同様に $T_{\mathrm{c}}$ の 減少とともに $J_{\mathrm{c}}(40 \mathrm{~K}, 3 \mathrm{~T})$ も減少した

\section{3 $F_{\mathrm{p}, \max }$ 向上のために求められるナノロッド構造}

これらの解析結果は $J_{\mathrm{c}}\left(B<B_{\Phi}\right) / J_{\mathrm{c}}(0 \mathrm{~T})$ の $B_{\Phi}$ 依存性, $B_{\Phi}$ による $F_{\mathrm{p}, \max }$ のピークシフト, $T_{\mathrm{c}}$ の $J_{\mathrm{c}}$ 絶対值への効果に よって $F_{\mathrm{p}, \max }$ が決まっていることを示している。本研究では $77 \mathrm{~K}$ の $F_{\mathrm{p}, \max }$ が Table 2 の文献の結果と比較して小さかった. $77 \mathrm{~K}$ 近傍の高温では $J_{\mathrm{c}}$ 絶対值の $T_{\mathrm{c}}$ 依存性および $J_{\mathrm{c}}\left(B<B_{\Phi}\right) / J_{\mathrm{c}}(0 \mathrm{~T})$ の $B_{\Phi}$ 依存性の影響がともに強く, $\mathrm{YBCO}+\mathrm{BHO}(850)$ では $B_{\Phi}$ による $F_{\mathrm{p}, \max }$ のピークシフトの効 果で補うことができなった。 したがって高い $F_{\mathrm{p}, \max }$ を得るに
は $B_{\Phi}$ がある程度低く， $T_{\mathrm{c}}$ が高いことが求められる。この観 点から $77 \mathrm{~K}$ 近傍の高温の $F_{\mathrm{p}, \text { max }}$ を向上させるには成膜温度 を高くすることが有効である.

一方 $40 \mathrm{~K}$ の低温では $T_{\mathrm{c}}\left(T_{\mathrm{c}}{ }^{\mathrm{str}}\right)$ が $3 \mathrm{~K}$ 程度低いにもかかわ らず本研究では高い $F_{\mathrm{p}, \max }$ が得られた. 本研究は文献 3$)$, 18），20）と比較して $F_{\mathrm{p}, \text { max }}$ が得られた磁場がわずかに高く なっている. $F_{\mathrm{p}, \max }$ のピークシフトの効果が支配的となった ため $\mathrm{YBCO}+\mathrm{BHO}(850)$ で高い $F_{\mathrm{p}, \max }$ が得られた。これは $T_{\mathrm{c}}$ が多少低くなったとしても $B_{\Phi}$ を向上させることで $F_{\mathrm{p}, \max }$ を 向上させることができることを示している．この観点から $40 \mathrm{~K}$ 以下の低温の $F_{\mathrm{p}, \max }$ を向上させるには成膜温度を低く することが有効である.

このように本研究では $B_{\Phi}$ と $T_{\mathrm{c}}$ を変化させることにより $J_{\mathrm{c}}$ 特性を制御した。 $B_{\Phi}$ と $T_{\mathrm{c}}$ を最適化したうえでさらなる $J_{\mathrm{c}}$ 特 性向上を実現するためには，ハイブリッドピンニング ${ }^{21,24)}$ 界面やひずみの原子スケール構造制御等に着目して 9,10$)$ さら なる薄膜構造制御を行っていく必要がある.

\section{5. ま と め}

PLDにおいて成膜温度を $830-900^{\circ} \mathrm{C}$ に変化させて YBCO+BHO 薄膜を作製し, ナノロッド構造を変化させた. $77 \mathrm{~K}$ では $900^{\circ} \mathrm{C}$ で作製した試料において最も高い $F_{\mathrm{p}, \text { max }}=$

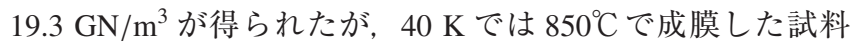
においてに高い $F_{\mathrm{p}, \max }=413 \mathrm{GN} / \mathrm{m}^{3}$ が得られた. 成膜温度が 低くなるにつれて $T_{\mathrm{c}}$ は低下し， $B_{\Phi}$ は増加した， $T_{\mathrm{c}}$ と $B_{\Phi}$ を もとに $F_{\mathrm{p}, \text { max }}$ を解析したところ， $T_{\mathrm{c}}$ が高く $B_{\Phi}$ が小さくなる $900^{\circ} \mathrm{C}$ 成膜は $77 \mathrm{~K}$ の $F_{\mathrm{p}, \max }$ 向上に有効であるのに対し, $T_{\mathrm{c}}$ が 多少低くなったとしても $B_{\Phi}$ が高くなる $850^{\circ} \mathrm{C}$ 成膜が $40 \mathrm{~K}$ 以 下の低温の $F_{\mathrm{p}, \max }$ 向上に有効であることが分かった.

本研究の一部は JSPS 科研費基盤 B (18H01478)によって支 援を受けた。また測定の一部は東北大学金属材料研究所(附 属強磁場超伝導材料研究センター)における共同利用 (17H0047)によって行われた。

文献

1) X. Obradors and T. Puig: Supercond. Sci. Technol. 27 (2014) 044003.

2) V. Chepikov, N. Mineev, P. Degtyarenko, S. Lee, V. Petrykin, A. Ovcharov, A. Vasiliev, A. Kaul, V. Amelichev and A. Kamenev: Supercond. Sci. Technol. 30 (2017) 124001.

3) V. Selvamanickam, M.H. Gharahcheshmeh, A. Xu, Y. Zhang and E. Galstyan: Supercond. Sci. Technol. 28 (2015) 072002.

4) J.L. MacManus-Driscoll, S.R. Foltyn, Q.X. Jia, H. Wang, A. Serquis, L. Civale, B. Maiorov, M.E. Hawley, M.P. Maley and D.E. Peterson Nat. Mater. 3 (2004) 439-443.

5) A. Goyal, S. Kang, K.J. Leonard, P.M. Martin, A.A. Gapud, M. Varela, M. Paranthaman, A.O. Ijaduola, E.D. Specht, J.R. Thompson, D.K Christen, S.J. Pennycook and F.A. List: Supercond. Sci. Technol. 18 (2005) 1533-1538.

6) P. Mele, K. Matsumoto, T. Horide, A. Ichinose, M. Mukaida, Y. Yoshida, S. Horii and R. Kita: Supercond. Sci. Technol. 21 (2008) 032002.

7) H. Tobita, K. Notoh, K. Higashikawa, M. Inoue, T. Kiss, T. Kato, T Hirayama, M. Yoshizumi, T. Izumi and Y. Shiohara: Supercond. Sci. Technol. 25 (2012) 062002.

8) T. Horide, K. Taguchi, K. Matsumoto, N. Matsukida, M. Ishimaru, P. Mele and R. Kita: Appl. Phys. Lett. 108 (2016) 082601.

9) C. Cantoni, Y. Gao, S.H. Wee, E.D. Specht, J. Gazquez, J. Meng, S.J. 
Pennycook and A. Goyal: ACS Nano 5 (2011) 4783-4789.

10) T. Horide, F. Kametani, S. Yoshioka, T. Kitamura and K. Matsumoto: ACS Nano 11 (2017) 1780-1788.

11) T.J. Jackson and S.B. Palmer: J. Phys. D 27 (1994) 1581-1594.

12) S. Proyer, E. Stangl, M. Borz, B. Hellebrand and D. Bäuerle: Phys. C 257 (1996) 1-15.

13) B. Dam, J.H. Rector, J.M. Huijbregtse and R. Griessen: Phys. C 305 (1998) $1-10$

14) B. Maiorov, S.A. Baily, H. Zhou, O. Ugurlu, J.A. Kennison, P.C. Dowden, T.G. Holesinger, S.R. Foltyn and L. Civale: Nat. Mater. 8 (2009) 398-404.

15) S. Horii, H. Kai, M. Mukaida, K. Yamada, R. Teranishi, A. Ichinose, K. Matsumoto, Y. Yoshida, R. Kita, J. Shimoyama and K. Kishio: Appl. Phys. Lett. 93 (2008) 152506.

16) T. Ozaki, Y. Yoshida, Y. Ichino, Y. Takai, A. Ichinose, K. Matsumoto, S. Horii, M. Mukaida and Y. Takano: J. Appl. Phys. 108 (2010) 093905.

17) T. Horide, S. Nagao, R. Izutsu, M. Ishimaru, R. Kita and K. Matsumo- to: Supercond. Sci. Technol. 31 (2018) 065012.

18) S. Miura, Y. Yoshida, Y. Tsuchiya, Y. Ichino, S. Awaji, A. Ichinose, K. Matsumoto, A. Ibi, T. Izumi and M. Iwakuma: Appl. Phys. Express 10 (2017) 103101.

19) S. Miura, Y. Yoshida, Y. Ichino, A. Tsuruta, K. Matsumoto, A. Ichinose and S. Awaji: Supercond. Sci. Technol. 28 (2015) 114006.

20) S. Awaji, Y. Yoshida, T. Suzuki, K. Watanabe, K. Hikawa, Y. Ichino and T. Izumi: Appl. Phys. Express 8 (2015) 023101.

21) T. Horide, T. Kawamura, K. Matsumoto, A. Ichinose, M. Yoshizumi, T. Izumi and Y. Shiohara: Supercond. Sci. Technol. 26 (2013) 075019.

22) T. Horide, N. Matsukida, M. Ishimaru, R. Kita, S. Awaji and K. Matsumoto: Appl. Phys. Lett. 110 (2017) 052601.

23) H. Yamasaki and K. Endo: IEEE Trans. Appl. Supercond. 25 (2015) 7500504.

24) G. Ercolano, M. Bianchetti, S.C. Wimbush, S.A. Harrington, H. Wang, J.H. Lee and J.L. MacManus-Driscoll: Supercond. Sci. Technol. 24 (2011) 095012. 